\title{
Neonatal Clinical Nurse Specialist (CNS): The Importance of Specialized Nursing Care for NICU Patients and Families
}

Robin Koeppel, DNP, CPNP, CNS, RNC-NIC, C-ELBW, C-NNIC

“Decades ago, NICU CCS Standards required a neonatal Clinical Nurse Specialist (CNS). Visionary and innovative authors of these previous NICU CCS standards identified the importance of specialized nursing care for NICU patients and families and tasked the NICU CNS to serve as the nursing care expert and consultant for complex patient care needs."

Decades ago, NICU CCS Standards required a neonatal Clinical Nurse Specialist (CNS). Visionary and innovative authors of these previous NICU CCS standards identified the importance of specialized nursing care for NICU patients and families and tasked the NICU CNS to serve as the nursing care expert and consultant for complex patient care needs. With the changing complexity of nursing care in the NICU, additional technology used to care for NICU patients and families, and the increasing scope of the Registered Nurse (RN) at the bedside, the NICU CNS is needed now more than ever to assure quality nursing care is delivered consistently and reliably.

The Neonatal Nurse Practitioner (NNP) and Clinical Nurse Educator (CNE) are also vital and important, and each provides unique and distinct services to NICU patients and families, nursing and nursing staff, and the healthcare system. However, these roles are not interchangeable, and the skills, knowledge, and academic preparation are unique and distinct. Together, all three roles collaborate with the interdisciplinary team to enhance the quality of care delivered at the NICU bedside.

Recently, CCS distributed an updated draft of NICU standards for review and comment. Proposed modifications within the CCS NICU standards are to remove the NICU CNS role and replace

Readers can also follow NEONATOLOGY

via our Twitter Feed

@NEOTO it with a new title, "Neonatal Clinical Nurse Educator" (NCNE), which may be filled by a NICU CNS, NNP, or CNE. The responsibilities of the new NCNE are the same as the NICU CNS. This proposed modification demonstrates a lack of understanding of the skills and knowledge that each role (NICU CNS, NNP, and CNE) brings to the NICU. The California Neonatal CNS group drafted a response to the proposed CCS changes in an effort to clarify the differences between the NICU CNS, NNP, and CNE in both academic preparation and skills, focus, and scope of practice.

To all of our colleagues in the NICU, we respectfully share our response in hopes it will be informative and bring an understanding of and clarity to the CNS role in the NICU.

\section{"To all of our colleagues in the NICU, we respectfully share our response in hopes it will be informative and bring an understanding of and clarity to the CNS role in the NICU."}

\section{Dear California Children Services,}

The California Neonatal Nurse Specialist Group recently reviewed the proposed modifications to the California Children Services (CCS) Neonatal Intensive Care Unit (NICU) standards. The proposed "Neonatal Clinical Nurse Educator" (NCNE) and the grouping of Clinical Nurse Specialist (CNS), Neonatal Nurse Practitioner (NNP), or Certified Nurse Educator (CNE) to fulfill this category in the Regional, Community, and Intermediate facilities is inappropriate and would be a great disservice to NICU patients and families, nursing and nursing practice and healthcare systems. The NICU CNS has a nationally recognized, state-specific scope of practice that cannot be replaced by the scope of practice of other Advanced Practice Registered Nurses (APRN) or nurse educators (AACN, 2019). Additionally, this proposed change, allowing the fulfillment of the CNS role with non-CNS personnel, violates the Nurse Practice Act (Business and professions Code Division 2, Chapter 6, Article 9, Section 2838.2)

https://leginfo.legislature.ca.gov/faces/codes_displayText.xhtml? lawCode=BPC\&division=2.\&title=\&part=\&chapter=6. \&article=9.

We are committed to ensuring that all NICU infants, including those cared for in CCS-approved facilities, benefit from the full range of nursing services and competencies characteristic of CNS practice.

The purpose of this letter, and our recommended CCS NICU standard revisions (attached), is to share information and serve as a resource in understanding the differences between and among roles and, ultimately, to better serve the NICUs across California.

The NICU CNS is the clinical nursing care expert whose overarching goal is to improve neonatal patient outcomes and promote the health of neonatal communities and populations. The CNS 
and NNP, both APRNs, have distinct and separate practice characteristics with specific and unique academic preparation, skills, and knowledge. The primary role of the CNS is to continuously improve the nursing care of patients, resulting in improved patient outcomes (ANA, 2010). The CNS has a broader focus, directly impacting the delivery of neonatal patient care by impacting nurses and nursing staff, families, and organizational systems. The CNS provides both direct and indirect patient care and serves as an interprofessional liaison between administration, medicine, nursing, and other disciplines in a system's context. Utilizing each CNS sub role and the standards developed by CCS, the CNS provides not only nursing education but also consults on complex nursing care issues, participates in developing and providing family education, assists in maintaining the clinical development of the nursing staff, and ensures a coordinated and effective discharge planning program. Additionally, the CNS conducts and participates in clinical research studies and utilizes research findings to make changes in nursing practice. Increasingly, the CNS leads the interprofessional team in Quality Improvement (QI) projects improving NICU patient and family outcomes. Multiple examples of CNS-led QI projects exist on both the CMQCC and CPQCC QI Collaborative sites, as well as other quality of care networks committed to improving the health of neonates and their families.

In contrast, the primary role of the NNP is to provide acute care management of ill infants and their families at the point of care. The NNP's academic preparation, skills, and knowledge do not include teaching or developing an educational curriculum, nor are they trained in organizational systems and change management. The NNP collaborates with other members of the team to assure expert neonatal care delivery. Although very skilled in the medical management of sick newborns, the priority of NNP role is not to provide consultation to the nursing staff on complex patient care nursing management. Her focus is direct patient care assessment and treatment.

The primary role of the CNE is as an expert in education, designing, developing, and executing educational programs based on adult learning theory utilizing the latest, evidence-based educational methodologies. The CNE is not an APRN, and the academic preparation, skills, and knowledge are centered on curriculum development and teaching. The CNE is not a nursing care expert, cannot consult on NICU patients with complex nursing care issues. The CNS, not the CNE, is prepared in advanced patient care and can consistently utilize these expert skills within a framework of an advanced direct patient care perspective. It is this distinctive combination that distinguishes CNS practice from that of a CNE. Although the CNE may have some skill and expertise, it is the CNS that is uniquely prepared by higher education and experience to function at an advanced level of nursing practice (NACNS, 2019). Rather, it would be appropriate to support close collaboration between the CNS and CNE as the CNS provides the evidenced-based practice, quality control, and policy development to help the CNE build comprehensive educational components for the staff.

As a state-wide group of NICU CNSs working in Intermediate, Community, and Regional NICUs, we emphatically oppose the proposed interchangeability of these roles in meeting the responsibilities outlined within the proposed CCS standards. The CNS is the only APRN who possesses the skills, knowledge, and academic preparation to serve as the nursing care expert (over 500 supervised hours by a NICU CNS is required prior to certification as a CNS by the Board of Registered Nursing) and consult on complex critical care nursing issues, not only in the NICU but interdepartmentally where any neonate may be in the hospital. Additionally, with the expanding scope of the Registered Nurse (RN) in the NICU, increased use of technology for patient care monitoring and treatment, and increased focus on quality outcomes, the CNS is the most appropriately prepared role to meet the needs of the changing RN patient care environment.
"As a state-wide group of NICU CNSs working in Intermediate, Community, and Regional NICUs, we emphatically oppose the proposed interchangeability of these roles in meeting the responsibilities outlined within the proposed CCS standards."

We understand the lack of available neonatal CNSs in California in the past may have posed a hardship for NICUs hiring a CNS for this role. This may have been the impetus in proposing different nursing roles to fulfill the necessary and vital responsibilities under "NICU Professional Resources and Requirements" in all three CCS standards. We respectfully inform CCS and all stakeholders that there are now two public Neonatal CNS programs in California (University of California, San Francisco and California State University, Dominguez Hills), both actively preparing and graduating NICU CNSs. The functions and responsibilities noted within the Standards have been and will always be best served by a NICU CNS, who has the scope, academic preparation, expertise, and knowledge to meet the needs of the specialized infant and family population in the NICU.

\section{In summary, we respectfully recommend:}

1. The title "Neonatal Clinical Nurse Educator (NCNE)" be abandoned, and the Neonatal Clinical Nurse Specialist be the role and title that meets the responsibilities outlined under "NICU Professional Resources and Requirements" in all three CCS Standards for Regional, Community, and Intermediate NICUs.

2. The CNS be one full-time equivalent for both Regional and Community level NICUs

3. A CNE be recommended in addition to, but not in place of the CNS for both Regional and Community level NICU

Thank you in advance for your consideration. We are happy to discuss further the CNS role in the NICU. Sincerely,

\section{CA Neonatal CNS Group}

\section{References:}

1. https://leginfo.legislature.ca.gov/faces/codes displayText. $x$ html? lawCode=BPC\&division $=2 . \&$ title $=\&$ part $=\& \mathrm{ch}$ apter=6. \&article=9.

Disclosures: The author does not have any relevant disclosures. 


\begin{tabular}{|c|c|}
\hline $\begin{array}{l}\text { Cindy Sessler, RNC, MSN, CNS } \\
\text { Neonatal Clinical Nurse Specialist } \\
\text { Loma Linda University Children's } \\
\text { Hospital } \\
\text { Loma Linda, CA }\end{array}$ & $\begin{array}{l}\text { Rachelle Sey, PhD(c), APRN, CNS, RNC-NIC } \\
\text { Neonatal Clinical Nurse Specialist } \\
\text { Sharp Mary Birch Hospital for Women \& Newborns } \\
\text { San Diego, California }\end{array}$ \\
\hline $\begin{array}{l}\text { Anna M. Muñoz, DNP, MPH, CNS-BC, } \\
\text { RNC-NIC } \\
\text { Neonatal Clinical Nurse Specialist } \\
\text { Providence Holy Cross Medical Center } \\
\text { Mission Hills, CA }\end{array}$ & $\begin{array}{l}\text { Holly O'Quinn, DNP APRN ACCNS-N CCRN } \\
\text { RNC-NIC C-NNIC C-ELBW } \\
\text { Neonatal Clinical Nurse Specialist } \\
\text { Children's Hospital Orange County } \\
\text { Orange, CA }\end{array}$ \\
\hline $\begin{array}{l}\text { Liz Drake MN, RNC-NIC, NNP, CNS, C- } \\
\text { ELBW } \\
\text { Neonatal Clinical Nurse Specialist } \\
\text { CHOC Children's at Mission Hospital } \\
\text { Mission Viejo, CA }\end{array}$ & $\begin{array}{l}\text { Starlynn Dris, MSN, RNC-NIC, ACCNS-N } \\
\text { Kaiser Permanente } \\
\text { San Francisco Medical Center } \\
\text { San Francisco, CA }\end{array}$ \\
\hline $\begin{array}{l}\text { Jeanne Wilkins MS RN NNP-BC CNS } \\
\text { Neonatal Clinical Nurse Specialist } \\
\text { Sutter Medical Center } \\
\text { Sacramento, CA }\end{array}$ & $\begin{array}{l}\text { Ching Ching Tay, MS, CNS, RNC-NIC, C-ONQS } \\
\text { Neonatal Clinical Nurse Specialist } \\
\text { Miller Children's \& Women's Hospital } \\
\text { Long Beach, CA }\end{array}$ \\
\hline $\begin{array}{l}\text { Karen Rose, MSN, RN, ACCNS-N, } \\
\text { RNC-NIC } \\
\text { Clinical Nurse Coordinator, NICU } \\
\text { Cottage Children's Medical Center } \\
\text { Santa Barbara, CA }\end{array}$ & $\begin{array}{l}\text { Donna Jensen, MSN, MHA, RNC-NIC, PHN, CNS } \\
\text { Clinical Nurse Specialist, Neonatal Intensive Care } \\
\text { Unit } \\
\text { Dignity Health, Bakersfield Memorial Hospital } \\
\text { Bakersfield, CA }\end{array}$ \\
\hline $\begin{array}{l}\text { Elizabeth Papp, MSN, RNC, CNS, FNP } \\
\text { Clinical Nurse Specialist, Intensive Care } \\
\text { Nursery } \\
\text { UCSF Benioff Children's Hospital } \\
\text { San Francisco, CA }\end{array}$ & $\begin{array}{l}\text { Nancy Simmons, MSN, RNC-NIC, CNS } \\
\text { Clinical Nurse Specialist NICU } \\
\text { Emanate Health Queen of the Valley Hospital } \\
\text { West Covina, CA }\end{array}$ \\
\hline $\begin{array}{l}\text { Beverly Walti RNC-NIC, MSN, CPNP, } \\
\text { CNS } \\
\text { Neonatal Clinical Nurse Specialist } \\
\text { CHOC Children's } \\
\text { Orange Ca }\end{array}$ & $\begin{array}{l}\text { Andrea C Morris, DNP, RNC-NIC, CCRN, CNS } \\
\text { Neonatal Clinical Nurse Specialist } \\
\text { Kaiser Permanente-Fontana } \\
\text { Part-time faculty NICU CNS program } \\
\text { California State University: Dominguez Hills }\end{array}$ \\
\hline $\begin{array}{l}\text { Christine Retta, MSN, RNC, NNP-BC, } \\
\text { CNS } \\
\text { Interim NICU Clinical Nurse Specialist } \\
\text { Kaiser Permanente Medical Center } \\
\text { Santa Clara, CA }\end{array}$ & $\begin{array}{l}\text { Elena Ornelas-Pelaez, MSN, RN, APRN, PNP, } \\
\text { CNS, RNC-NIC, NTMNC, IBCLC } \\
\text { Clinical Nurse Specialist - NICU } \\
\text { Kaiser Permanente Panorama City } \\
\text { Panorama City, CA }\end{array}$ \\
\hline $\begin{array}{l}\text { Lori J. Wood, MSN, CNS, RNC-NIC, } \\
\text { IBCLC } \\
\text { Neonatal Clinical Nurse Specialist, } \\
\text { Desert Regional Medical Center } \\
\text { Palm Springs, Ca }\end{array}$ & $\begin{array}{l}\text { Kathi Randall, MSN, CNS, NNP-BC } \\
\text { Neonatal Clinical Nurse Specialist } \\
\text { Synapse Care Solutions }\end{array}$ \\
\hline $\begin{array}{l}\text { Juliet Sasinski MSN, CNS, RNC-NIC, } \\
\text { C-ELBW } \\
\text { Neonatal Clinical Nurse Specialist } \\
\text { UCLA Health } \\
\text { Los Angeles, CA }\end{array}$ & $\begin{array}{l}\text { Heaven Holdbrooks, RN, MSN, PNP, CNS, RNC- } \\
\text { NIC } \\
\text { Clinical Nurse Specialist } \\
\text { Neonatal Intensive Care } \\
\text { Kaiser Permanente OC- Anaheim }\end{array}$ \\
\hline Carolyn Lund RN, MS, FAAN & Alison Brooks, RNC, MS, CNS \\
\hline
\end{tabular}




\begin{tabular}{|c|c|}
\hline $\begin{array}{l}\text { Neonatal Clinical Nurse Specialist } \\
\text { UCSF Benioff Children's Hospital } \\
\text { Oakland, CA }\end{array}$ & $\begin{array}{l}\text { Neonatal Clinical Nurse Specialist } \\
\text { Alta Bates Summit } \\
\text { Berkeley, CA }\end{array}$ \\
\hline $\begin{array}{l}\text { Susan M. Bowles, DNP APRN-CNS, } \\
\text { RNC-NIC,CBC } \\
\text { Neonatal Clinical Nurse Specialist }\end{array}$ & $\begin{array}{l}\text { Jeannie Chan, MS, RN, NNP-BC, CNS } \\
\text { Clinical Nurse Specialist, Intensive Care Nursery } \\
\text { UCSF Benioff Children's Hospital } \\
\text { San Francisco, CA }\end{array}$ \\
\hline $\begin{array}{l}\text { Shannon Tinkler, MSN, CNS, RNC-NIC } \\
\text { Neonatology Educator, Neonatal Special } \\
\text { Services } \\
\text { Sutter Health, California Pacific Medical } \\
\text { Center } \\
\text { San Francisco, CA }\end{array}$ & $\begin{array}{l}\text { Michelle D. Rhein, MSN, CNS, RNC-NIC } \\
\text { California Pacific Medical Center }\end{array}$ \\
\hline $\begin{array}{l}\text { Peggy Grimm, MS, NP, CNS, RNC-NIC } \\
\text { Rady Children's Hospital } \\
\text { San Diego, CA }\end{array}$ & $\begin{array}{l}\text { Lorraine Shields, DNP, APRN, CNS, NNP-BC } \\
\text { DNP Program Director } \\
\text { California Baptist University }\end{array}$ \\
\hline $\begin{array}{l}\text { Robin L. Watson, RN, MN, CNS, } \\
\text { CCRN-K } \\
\text { Assistant Nursing Director } \\
\text { Los Angeles County Department of } \\
\text { Health Services - Health Services } \\
\text { Administration }\end{array}$ & $\begin{array}{l}\text { Christa Bedford-Mu, RN, MSN, CNS, CCRN, C- } \\
\text { ELBW } \\
\text { Clinical Nurse Specialist } \\
\text { Neonatal Intensive Care Units } \\
\text { UC Davis Children's Hospital }\end{array}$ \\
\hline $\begin{array}{l}\text { Stacie Venkatesan, MSN, CNS, RNC- } \\
\text { NIC } \\
\text { Director of Critical Care } \\
\text { Valley Children's Healthcare }\end{array}$ & Amy Paradis, RN, MS, NNP-BC, CNS \\
\hline $\begin{array}{l}\text { Marie Togashi, MSN, CNS, RNC-NIC } \\
\text { Clinical Nurse Specialist Neonatal ICU } \\
\text { Education Coordinator } \\
\text { Hoag Memorial Hospital Presbyterian } \\
\text { Newport Beach, CA }\end{array}$ & $\begin{array}{l}\text { Deborah Camara MSN NNP-BC, CPNP. C-NPT, } \\
\text { C-CNS } \\
\text { Neonatal Nurse Practitioner with Valley Neonatal } \\
\text { Medical Associates, } \\
\text { Providence Saint Joseph Medical Center } \\
\text { Glendale Memorial Medical Center } \\
\text { Adventist Health Glendale } \\
\text { USC Verdugo Hills Medical Center }\end{array}$ \\
\hline $\begin{array}{l}\text { Christine Broome, MSN, APRN-CNS, } \\
\text { RNC-NIC } \\
\text { Neonatal Clinical Nurse Specialist } \\
\text { Professional Development Specialist - } \\
\text { NICU } \\
\text { John Muir Health } \\
\text { Walnut Creek, CA }\end{array}$ & $\begin{array}{l}\text { Louise Mitchell MSN, CNS, RNC-NIC } \\
\text { Clinical Nurse Specialist, NICU } \\
\text { PIH Health Whittier Hospital } \\
\text { Whittier, CA }\end{array}$ \\
\hline $\begin{array}{l}\text { Terri Ares, PhD, RNC-NIC, CNS-BC } \\
\text { Graduate Program Coordinator } \\
\text { \& CNS Role Advisor } \\
\text { School of Nursing } \\
\text { California State University, Dominguez } \\
\text { Hills } \\
\text { Carson, CA }\end{array}$ & $\begin{array}{l}\text { Devang Patel MD, MS } \\
\text { Medical Director NICU, } \\
\text { PIH Health Whittier Hospital } \\
\text { Whittier, CA }\end{array}$ \\
\hline $\begin{array}{l}\text { Mary Dix MSN, CNS, RNC-NIC } \\
\text { Clinical Nurse Specialist, NICU } \\
\text { PIH Health Whittier Hospital }\end{array}$ & $\begin{array}{l}\text { Melinda Porter, MS, RN, CNS, NNP-BC, C-NNIC } \\
\text { Neonatal Clinical Nurse Specialist/Nurse } \\
\text { Practitioner }\end{array}$ \\
\hline
\end{tabular}




\begin{tabular}{|c|c|}
\hline Whittier, CA & $\begin{array}{l}\text { El Camino Health } \\
\text { Mountain View, CA }\end{array}$ \\
\hline $\begin{array}{l}\text { Lucinda Collinson, MSN, RN, CNS, } \\
\text { NNP-BC } \\
\text { Clinical Nurse Educator } \\
\text { Neonatal Intensive Care Unit } \\
\text { UCSF Benioff Children's Hospital } \\
\text { Oakland } \\
\text { Oakland, CA }\end{array}$ & $\begin{array}{l}\text { Melanie Myers, DNP, CNS, RNC-NIC, C-ONQS } \\
\text { Clinical Nurse Specialist } \\
\text { Women \& Children Services } \\
\text { Huntington Hospital } \\
\text { Pasadena, CA }\end{array}$ \\
\hline $\begin{array}{l}\text { Ja-Yee Ann Chu DNP, CNS, CCRN-K, } \\
\text { C-NNIC } \\
\text { Clinical Nurse Specialist, Neonatal ICU } \\
\text { Kaiser Permanente - Los Angeles } \\
\text { Medical Center } \\
\text { Los Angeles, CA }\end{array}$ & $\begin{array}{l}\text { Linda A Wynsma, RNC-NIC, MSN, CNS } \\
\text { NICU Clinical Nurse Specialist } \\
\text { Kaiser Permanente Downey Medical Center } \\
\text { Downey, CA }\end{array}$ \\
\hline $\begin{array}{l}\text { Jennifer Norgaard, RNC-NIC, MSN, } \\
\text { ACCNS-P } \\
\text { Neonatal Clinical Nurse Specialist } \\
\text { Valley Children's Health Care } \\
\text { Madera, CA }\end{array}$ & $\begin{array}{l}\text { Margaretha Cash, MSN, CNS, RNC-NIC } \\
\text { Neonatal Intensive Care Unit } \\
\text { Pomona Valley Hospital Medical Center } \\
\text { Pomona, CA }\end{array}$ \\
\hline $\begin{array}{l}\text { Helen J. Nguyen DNP, NNP, CNL, CNS } \\
\text { Clinical Nurse Specialist, Neonatal } \\
\text { Intensive Care Unit } \\
\text { Kaiser San Leandro Medical Center }\end{array}$ & $\begin{array}{l}\text { Patty Hanighen, MN, CNS, RNC-NIC, NE-BC } \\
\text { CHOC Children's Hospital } \\
\text { Orange CA, } 92868\end{array}$ \\
\hline $\begin{array}{l}\text { Nida Lovatanapongsa, MSN, CNS, } \\
\text { CCRN }\end{array}$ & $\begin{array}{l}\text { Lourdes Arteaga, MSN, CNS, RNC-NIC } \\
\text { NICU Clinical Nurse Specialist } \\
\text { Providence St. Joseph Medical Center } \\
\text { Buena Vista, CA }\end{array}$ \\
\hline $\begin{array}{l}\text { Peggy Holub MSN, RNC-NIC, CNS, } \\
\text { WTA-C } \\
\text { Neonatal Intensive Care Clinical Nurse } \\
\text { Specialist } \\
\text { Rady Children's Hospital } \\
\text { San Diego, CA }\end{array}$ & Stella Riddell DNP, RN, CNS, RNC-NIC \\
\hline $\begin{array}{l}\text { Ellen Mack, MN, RNC-NIC, Neonatal } \\
\text { CNS, CPHQ }\end{array}$ & $\begin{array}{l}\text { Annette Carley DNP RN NNP-BC PPCNP-BC } \\
\text { Clinical Professor } \\
\text { Associate Director DNP Program } \\
\text { UCSF School of Nursing } \\
\text { San Francisco, CA }\end{array}$ \\
\hline $\begin{array}{l}\text { Ann McCarthy DeMaio DNP, CCNS, } \\
\text { NNP-BC }\end{array}$ & $\begin{array}{l}\text { Joanne Kuller RNC-NIC, MS, CNS } \\
\text { Neonatal Clinical Nurse Specialist } \\
\text { UCSF Benioff Children's Hospital Oakland } \\
\text { Oakland, CA }\end{array}$ \\
\hline
\end{tabular}

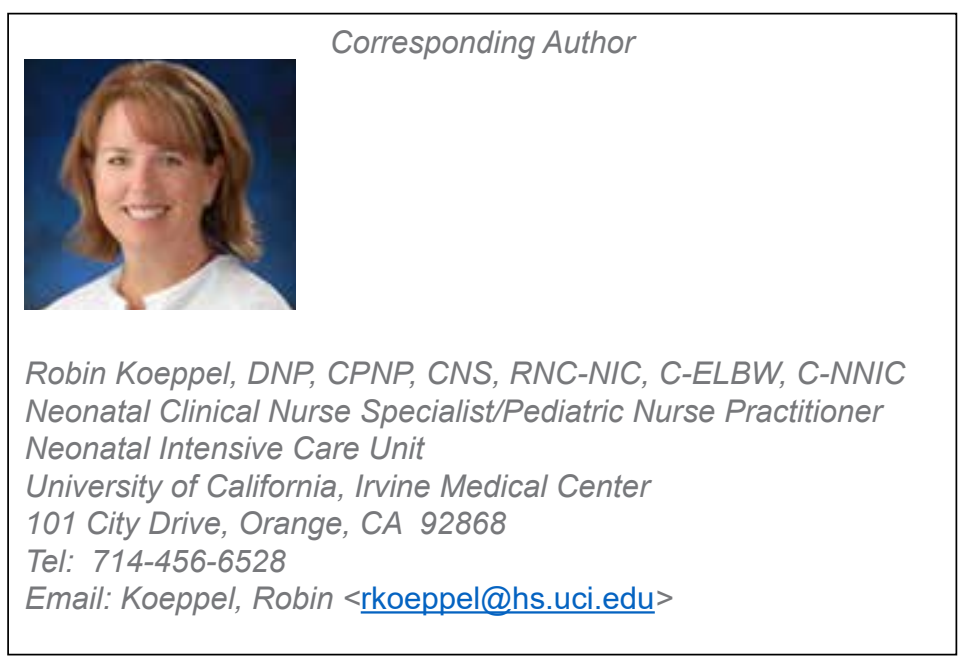

